\title{
Stable pantothenamide bioisosteres: novel antibiotics for Gram-positive bacteria
}

\author{
Patrick A. M. Jansen ${ }^{1} \cdot$ Danique A. van der Krieken ${ }^{1} \cdot$ Peter N. M. Botman ${ }^{2} \cdot$ Richard H. Blaauw $^{2} \cdot$ Lorenzo Cavina $^{2}$. \\ Eline M. Raaijmakers ${ }^{2}$ - Erik de Heuvel ${ }^{2}$ - Julia Sandrock ${ }^{2}$ Lian J. Pennings ${ }^{3}$ - Pedro H. H. Hermkens ${ }^{4}$. \\ Patrick L. J. M. Zeeuwen ${ }^{1} \cdot$ Floris P. J. T. Rutjes ${ }^{5} \cdot$ Joost Schalkwijk $^{1}$
}

Received: 15 February 2019 / Revised: 6 May 2019 / Accepted: 10 May 2019 / Published online: 6 June 2019

(c) The Author(s) 2019. This article is published with open access

\begin{abstract}
The emergence of multidrug resistant bacteria has prioritized the development of new antibiotics. $N$-substituted pantothenamides, analogs of the natural compound pantetheine, were reported to target bacterial coenzyme A biosynthesis, but these compounds have never reached the clinic due to their instability in biological fluids. Plasma-stable pantothenamide analogs could overcome these issues. We first synthesized a number of bioisosteres of the prototypic pantothenamide N7-Pan. A compound with an inverted amide bond (CXP18.6-012) was found to provide plasma-stability with minimal loss of activity compared to the parent compound N7-Pan. Next, we synthesized inverted pantothenamides with a large variety of side chains. Among these we identified a number of novel stable inverted pantothenamides with selective activity against Gram-positive bacteria such as staphylococci and streptococci, at low micromolar concentrations. These data provide future direction for the development of pantothenamides with clinical potential.
\end{abstract}

\section{Introduction}

There is an ongoing need for new drug scaffolds and targets to combat the increasing development of resistant bacterial strains. Methicillin-resistant and vancomycin-resistant Staphylococcus aureus (S. aureus) strains (MRSA and VRSA) have led to serious health problems in both hospital settings

Supplementary information The online version of this article (https:// doi.org/10.1038/s41429-019-0196-6) contains supplementary material, which is available to authorized users.

Patrick A. M. Jansen

Patrick.jansen@ radboudumc.nl

$\bowtie$ Joost Schalkwijk

Joost.schalkwijk@radboudumc.nl

1 Department of Dermatology, Radboud University Medical Center, Nijmegen, The Netherlands

2 Chiralix, Nijmegen, The Netherlands

3 Department of Medical Microbiology, Radboud University Medical Center, Nijmegen, The Netherlands

4 Hermkens Pharma Consultancy, Oss, The Netherlands

5 Institute for Molecules and Materials, Radboud University, Nijmegen, The Netherlands and the community, but resistance to antibiotics is certainly not limited to these examples. Pantothenate or pantothenic acid (vitamin B5) is required for coenzyme A (CoA) biosynthesis and is an essential and rate limiting nutrient for survival and/or growth of numerous bacteria, fungi and protozoa. A range of compounds analogous to pantothenate or to its cysteamine conjugate pantetheine (see Fig. 1a) have been reported that possess activity against bacteria, fungi and malaria parasites (for a review see ref. [1]). In 1970, $N$-substituted pantothenamides (in short: pantothenamides), were first reported to possess antibacterial activity in vitro (see Fig. $1 \mathrm{~b}$ for the general pantothenamide structure) [2]. Pantothenamides are pantetheine analogs, of which the prototypic members $N$-pentylpantothenamide (N5-Pan) and $N$-heptylpantothenamide (N7-Pan) were found to be active against Gram-negative and Gram-positive bacteria [3]. During the last few decades, a number of additional pantothenamides with antibacterial activity have been synthesized [4-8] and their putative modes of action have been studied in detail [7-11]. Pantothenamides have been shown to serve as substrates or inhibitors (either competitive or allosteric) of pantothenate kinase (PanK), the first enzyme in the CoA biosynthesis pathway $[4,5,7,8]$. As a consequence, PanKcatalyzed pantothenate phosphorylation is partially or completely inhibited. In the case that pantothenamides serve as 
Fig. 1 General structures: a Chemical structure of pantetheine. b General structure of pantothenamide and its products pantothenic acid and the corresponding amine after hydrolysis by vanins. The vanin sensitive amide bond is marked as well as the C2-linker between the amides
A<smiles>CC(C)(C)C(O)[C@H](O)C(=O)NCCC(=O)NCCS</smiles>

B

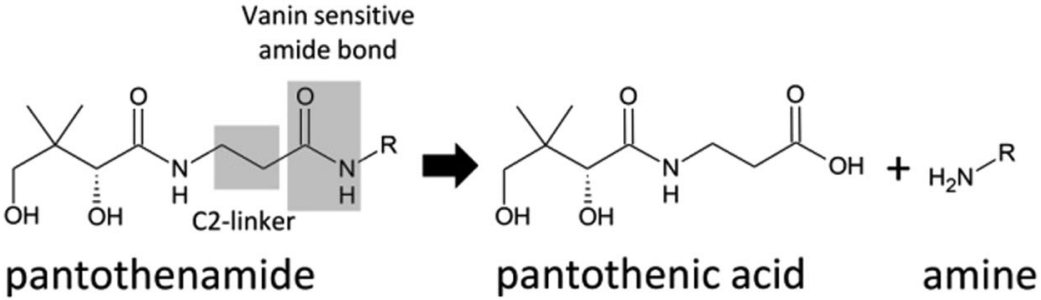

PanK substrates, competing with the natural substrate pantothenic acid, the resulting $4^{\prime}$-phosphopantothenamides may be further metabolized by the CoA biosynthetic machinery to yield analogs of CoA, as was shown for Escherichia coli (E. coli) [9, 10]. Such CoA analogs were found to be incorporated in acyl carrier protein, thereby inhibiting its function in bacterial fatty acid biosynthesis, which requires the $4^{\prime}$-phosphopantetheine moiety of CoA to be active [12]. Whether the mechanisms that ultimately result in antimicrobial activity in the various target organisms (bacteria, fungi, protozoa) are the result of inhibition of CoA biosynthesis, fatty acid biosynthesis or another CoA-utilizing process, or a combination of the above, remains to be resolved for most organisms. The mechanism of action in $S$. aureus, however, has recently been investigated in detail indicating that PanK is the target enzyme [7].

Despite their potential use and selectivity for bacterial, fungal, and/or protozoan metabolic routes, no pantothenamide compound has ever made it to the clinic. It was recently shown that pantothenamides are not active as antimicrobials in the presence of serum, and that they were hydrolyzed by ubiquitous pantetheinases of the vanin family (see Fig. 1b) [13-16]. To address this, a series of vanin inhibitors based on a pantothenate scaffold were synthesized, which proved to inhibit serum vanin activity in the nanomolar range [17]. Combinations of these novel vanin inhibitors and prototypic pantothenamides like N5Pan and N7-Pan exert antimicrobial activity in vitro, particularly against Gram-positive bacteria (S. aureus, Staphylococcus epidermidis (S. epidermidis), Streptococcus pneumonia (S. pneumoniae), and Streptococcus pyogenes (S. pyogenes)) even in the presence of serum [18]. These results indicate that pantothenamides, when protected against degradation by host vanins, are potentially useful antimicrobial agents $[15,16]$.

As combinations of compounds are less desirable from a drug development perspective, chemical modification of pantothenamides to render them more stable would be preferable. Taking this approach, modified pantothenamides were generated that were active antimalarials or antibacterials in the presence of serum [19-23]. As the hydrolysis-susceptible amide bond was still present in these modifications or the potency was reduced significantly, we aimed to generate bioisosteric pantothenamides that would mimic the chemical space of the amide bond, but would lack the vanin sensitivity, without losing their potency. Here we describe such stable bioisosteric compounds as a starting point for lead optimization.

\section{Materials and methods}

\section{Chemistry of inverted pantothenamides}

\section{General procedure A}

To a solution of carboxylic acid $\mathbf{B}(0.5 \mathrm{mmol})$ in $\mathrm{MeCN} /$ $\mathrm{H}_{2} \mathrm{O}(30: 1,4.3 \mathrm{ml})$ were added $\mathrm{HOBt}(0.6 \mathrm{mmol}), \mathrm{NaHCO}_{3}$ $(0.6 \mathrm{mmol})$, EDCI $(0.6 \mathrm{mmol})$, and a solution of amine A (for the synthesis see ref 2, $0.6 \mathrm{mmol}$ ) in $\mathrm{MeCN} / \mathrm{H}_{2} \mathrm{O}$ $(0.7 \mathrm{ml})$. The progress of the reaction was monitored using LC-MS and upon completion, the reaction was quenched by the addition of saturated aqueous $\mathrm{NH}_{4} \mathrm{Cl}$ solution $(15 \mathrm{ml})$ and the mixture was extracted twice using EtOAc $(15 \mathrm{ml})$. The combined organic layers were dried over $\mathrm{Na}_{2} \mathrm{SO}_{4}$ and filtered before concentration under reduced pressure. The residue was purified by flash column chromatography $(\mathrm{DCM} / \mathrm{MeOH}=98: 2 \rightarrow 80: 20)$ to afford the product.

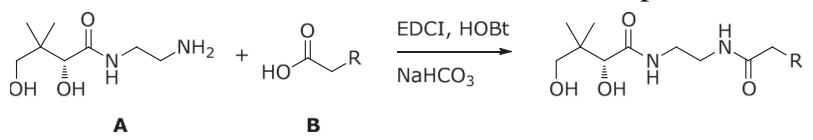

\section{CXP18.6-012}

According to general procedure A. Yield: 24\%, white solid. ${ }^{1} \mathrm{H}$ NMR (400 MHz, $\mathrm{CDCl}_{3}$ ): $\delta 7.23$ (br s, $1 \mathrm{H}$ ), 6.15 (br s, 1H), 4.01 (s, 1H), 3.84 (br s, 1H), 3.55-3.34 (m, 6H), 3.22 
(br s, 1H), 2.20-2.14 (m, 2H), 1.70-1.55 (m, 2H), 1.35-1.20 $(\mathrm{m}, 8 \mathrm{H}), 1.04(\mathrm{~s}, 3 \mathrm{H}), 0.96(\mathrm{~s}, 3 \mathrm{H}), 0.88(\mathrm{t}, J=6.9 \mathrm{~Hz}$, $3 \mathrm{H})$.

\section{CXP18.6-013}

According to general procedure A. Yield: 40\%, white solid. ${ }^{1} \mathrm{H} \mathrm{NMR}\left(400 \mathrm{MHz}, \mathrm{CDCl}_{3}\right.$ ): $\delta 7.28$ (br s, $1 \mathrm{H}$ ), 6.26 (br s, 1H), 4.10-3.97 (m, 2H), 3.55-3.30 (m, 7H), 2.21-2.13 $(\mathrm{m}, 2 \mathrm{H}) 1.65-1.55(\mathrm{~m}, 2 \mathrm{H}), 1.38-1.22(\mathrm{~m}, 4 \mathrm{H}), 1.03$ $(\mathrm{s}, 3 \mathrm{H}), 0.95(\mathrm{~s}, 3 \mathrm{H}), 0.88(\mathrm{t}, J=7.0 \mathrm{~Hz}, 3 \mathrm{H})$.

\section{CXP18.6-014}

According to general procedure A. Yield: 66\%, white solid. ${ }^{1} \mathrm{H}$ NMR (400 MHz, $\mathrm{CDCl}_{3}$ ): $\delta 7.27$ (br s, $\left.1 \mathrm{H}\right), 6.23$ (br s, 1H), 4.03-3.98 (m, 2H), 3.53-3.33 (m, 7H), 2.20-2.14 (m, 2H), 1.65-1.54 (m, 2H), 1.34-1.20 (m, 12H), $1.03(\mathrm{~s}, 3 \mathrm{H}), 0.95(\mathrm{~s}, 3 \mathrm{H}), 0.88(\mathrm{t}, J=6.9 \mathrm{~Hz}, 3 \mathrm{H})$.

\section{CXP18.6-017}

According to general procedure A. Yield: 35\%, colorless oil. ${ }^{1} \mathrm{H}$ NMR (400 MHz, $\left.\mathrm{CD}_{3} \mathrm{OD}\right): \delta$ 7.28-7.17 (m, 2H), 7.11-6.98 (m, 2H), 3.88 (s, 1H), 3.46 (d, J=11.0 Hz, 1H), $3.39(\mathrm{~d}, J=11.0 \mathrm{~Hz}, 1 \mathrm{H}), 3.33-3.22(\mathrm{~m}, 4 \mathrm{H}), 2.98-2.92$ (m, 2H), 2.51-2.54 (m, 2H), 0.92 (s, 3H), 0.92 (s, 3H).

\section{CXP18.6-069}

According to general procedure A. Yield: 43\%, colorless oil. ${ }^{1} \mathrm{H} \quad \mathrm{NMR} \quad\left(400 \mathrm{MHz}, \mathrm{CD}_{3} \mathrm{OD}\right): \delta 7.30-7.23 \quad(\mathrm{~m}, 1 \mathrm{H})$, 6.93-6.83 (m, 2H), $3.88(\mathrm{~s}, 1 \mathrm{H}), 3.46(\mathrm{~d}, J=11.0 \mathrm{~Hz}, 1 \mathrm{H})$, $3.39(\mathrm{~d}, J=11.0 \mathrm{~Hz}, 1 \mathrm{H}), 3.33-3.22$ (m, 4H), 2.92 (app t, $J=$ 7.7 Hz, 2H), 2.48-2.42 (m, 2H), 0.92 (s, 3H), 0.92 (s, 3H).

\section{CXP18.6-047}

According to general procedure A. Yield: 25\%, colorless oil. ${ }^{1} \mathrm{H}$ NMR (400 MHz, $\left.\mathrm{CD}_{3} \mathrm{OD}\right): \delta 7.18$ (dd, $J=5.1,1.2$ $\mathrm{Hz}, 1 \mathrm{H}), 6.90$ (dd, $J=5.1,3.4 \mathrm{~Hz}, 1 \mathrm{H}), 6.86-6.81(\mathrm{~m}, 1 \mathrm{H})$, 3.87 (s, 1H), 3.46 (d, $J=11.0 \mathrm{~Hz}, 1 \mathrm{H}), 3.39$ (d, $J=11.0$ $\mathrm{Hz}, 1 \mathrm{H}), 3.35-3.23$ (m, 4H), 3.17-3.09 (m, 2H), 2.56-2.49 (m, 2H), 0.92 (s, 3H), $0.92(\mathrm{~s}, 3 \mathrm{H})$.

\section{CXP18.6-057}

According to general procedure A. Yield: $48 \%$, off-white solid. ${ }^{1} \mathrm{H}$ NMR (400 MHz, $\left.\mathrm{CD}_{3} \mathrm{OD}\right): \delta 7.35$ (dd, $J=1.9$, $0.8 \mathrm{~Hz}, 1 \mathrm{H}), 6.28(\mathrm{dd}, J=3.2,1.9 \mathrm{~Hz}, 1 \mathrm{H}), 3.89(\mathrm{~s}, 1 \mathrm{H})$, $3.46(\mathrm{~d}, J=11.0 \mathrm{~Hz}, 1 \mathrm{H}), 3.39(\mathrm{~d}, J=11.0 \mathrm{~Hz}, 1 \mathrm{H})$, $3.36-3.25(\mathrm{~m}, 4 \mathrm{H}), 2.96-2.86(\mathrm{~m}, 2 \mathrm{H}), 2.55-2.45(\mathrm{~m}, 2 \mathrm{H})$, $0.93(\mathrm{~s}, 3 \mathrm{H}), 0.92$ (s, 3H).

\section{CXP18.6-064}

According to general procedure A. Yield: 92\%, colorless oil. ${ }^{1} \mathrm{H}$ NMR (400 MHz, $\left.\mathrm{CD}_{3} \mathrm{OD}\right): \delta 7.10(\operatorname{app~t}, J=7.9 \mathrm{~Hz}$, 1H), 6.92-6.83 (m, 2H), $3.88(\mathrm{~s}, 1 \mathrm{H}), 3.46(\mathrm{~d}, J=11.0 \mathrm{~Hz}$, $1 \mathrm{H}), 3.39(\mathrm{~d}, J=11.0 \mathrm{~Hz}, 1 \mathrm{H}), 3.33-3.22(\mathrm{~m}, 4 \mathrm{H})$, 2.94-2.85 (m, 2H), 2.48-2.40 (m, 2H), $2.30(\mathrm{~s}, 3 \mathrm{H}), 0.92$ (s, 3H), $0.91(\mathrm{~s}, 3 \mathrm{H})$.

\section{CXP14.18-005}

According to general procedure A. Yield: $25 \%$, colorless oil. ${ }^{1} \mathrm{H}$ NMR (400 MHz, $\mathrm{CDCl}_{3}$ ): $\delta 7.30$ (br s, $1 \mathrm{H}$ ), 6.32 (br $\mathrm{s}, 1 \mathrm{H}), 4.02(\mathrm{~s}, 1 \mathrm{H}), 3.51(\mathrm{~s}, 2 \mathrm{H}), 3.49-3.34(\mathrm{~m}, 4 \mathrm{H})$, 2.22-2.15 (m, 2H), 1.62-1.46 (m, 3H), 1.03 (s, 3H), 0.96 $(\mathrm{s}, 3 \mathrm{H}), 0.91(\mathrm{~s}, 3 \mathrm{H}), 0.89(\mathrm{~s}, 3 \mathrm{H})$.

\section{CXP14.18-012}

According to general procedure A. Yield: $88 \%$, white solid. ${ }^{1} \mathrm{H}$ NMR (400 MHz, $\mathrm{CDCl}_{3}$ ): $\delta 7.28$ (br s, $\left.1 \mathrm{H}\right), 6.26$ (br s, 1H), $4.01(\mathrm{~s}, 1 \mathrm{H}), 3.51(\mathrm{~s}, 2 \mathrm{H}), 3.50-3.31(\mathrm{~m}, 4 \mathrm{H})$, 2.20-2.14 (m, 2H), 1.65-1.55 (m, 2H), 1.37-1.18 (m, 16H), $1.30(\mathrm{~s}, 3 \mathrm{H}), 0.95(\mathrm{~s}, 3 \mathrm{H}), 0.88(\mathrm{t}, J=6.9 \mathrm{~Hz}, 3 \mathrm{H})$.

\section{CXP14.26-007}

According to general procedure A. Yield: 28\%, white waxy solid. ${ }^{1} \mathrm{H} \mathrm{NMR}\left(400 \mathrm{MHz}, \mathrm{CD}_{3} \mathrm{OD}\right): \delta 3.98$ (dd, $J=8.0$, $3.9 \mathrm{~Hz}, 1 \mathrm{H}), 3.89(\mathrm{~s}, 1 \mathrm{H}), 3.47(\mathrm{ABd}, J=10.9 \mathrm{~Hz}, 1 \mathrm{H})$, $3.40(\mathrm{ABd}, J=10.9 \mathrm{~Hz}, 1 \mathrm{H}), 3.40-3.30(\mathrm{~m}, 4 \mathrm{H}), 1.81-1.70$ $(\mathrm{m}, 1 \mathrm{H}), 1.63-1.52(\mathrm{~m}, 1 \mathrm{H}), 1.46-1.27(\mathrm{~m}, 4 \mathrm{H}), 1.0-0.85$ $(\mathrm{m}, 9 \mathrm{H})$.

\section{CXP14.18-037}

Amine A (1.50 g, $7.88 \mathrm{mmol})$ was dissolved in acetone (25 ml) and cooled to $4{ }^{\circ} \mathrm{C}$. 2-Methoxyprop-1-ene $(2.26 \mathrm{ml}$, $23.6 \mathrm{mmol})$ and $\mathrm{TsOH}(1.65 \mathrm{~g}, 8.67 \mathrm{mmol})$ were added and after $15 \mathrm{~min}$ the cooling bath was removed. The reaction was stirred for $18 \mathrm{~h}$ and then quenched by the addition of $\mathrm{Et}_{3} \mathrm{~N}$ (1.60 g, $15.7 \mathrm{mmol}$ ), followed by $12.5 \%$ aqueous ammonia $(15 \mathrm{ml})$. The mixture was extracted twice with DCM (15 ml) and the combined organic layers were concentrated under reduced pressure. The residue was purified by flash column chromatography (EtOAc/MeOH/25\% aq. $\left.\mathrm{NH}_{4} \mathrm{OH}=90: 10: 1 \rightarrow 50: 50: 1\right)$ to afford $1.07 \mathrm{~g}$ amine $\mathbf{C}$ as a colorless oil. Yield: $30 \%$. ${ }^{1} \mathrm{H}$ NMR (400 MHz, $\left.\mathrm{CD}_{3} \mathrm{OD}\right)$ : $\delta 4.15(\mathrm{~s}, 1 \mathrm{H}), 3.75(\mathrm{ABd}, J=11.7 \mathrm{~Hz}, 1 \mathrm{H}), 3.24-3.30$ $(\mathrm{m}, 3 \mathrm{H}), 2.73(\mathrm{~m}, 2 \mathrm{H}), 1.46(\mathrm{~s}, 3 \mathrm{H}), 1.45(\mathrm{~s}, 3 \mathrm{H}), 1.00$ (s, 3H), 0.99 (s, 3H).

To a solution of 2-(propylthio)acetic acid $(0.15 \mathrm{~g}, 0.81$ $\mathrm{mmol})$ in a mixture of $\mathrm{MeCN}(4.4 \mathrm{ml})$ and $\mathrm{H}_{2} \mathrm{O}(0.24 \mathrm{ml})$ 
were added HOBt $(0.11 \mathrm{~g}, 0.71 \mathrm{mmol})$, DIPEA $(0.14 \mathrm{ml}$, $0.81 \mathrm{mmol})$, EDC $(0.14 \mathrm{~g}, 0.72 \mathrm{mmol})$ and amine $\mathbf{C}(0.15 \mathrm{~g}$, $0.65 \mathrm{mmol})$. The reaction was stirred at room temperature for $2 \mathrm{~h}$, before the addition of EtOAc $(10 \mathrm{ml})$. The mixture was washed with saturated aqueous $\mathrm{NH}_{4} \mathrm{Cl}(10 \mathrm{ml})$, and saturated aqueous $\mathrm{NaHCO}_{3}(10 \mathrm{ml})$, dried over $\mathrm{Na}_{2} \mathrm{SO}_{4}$ and filtered before concentration under reduced pressure. The residue was purified by flash column chromatography $(\mathrm{EtOAc} / \mathrm{MeOH}=$ 95:5 $\rightarrow$ 90:10) to afford amide $\mathbf{D}(147 \mathrm{mg}, 65 \%)$.

To a solution of amide $\mathbf{D}(0.15 \mathrm{~g}, 0.42 \mathrm{mmol})$ in $\mathrm{MeCN}$ $(2.1 \mathrm{ml})$ was added an aqueous $0.2 \mathrm{M}$ solution of $\mathrm{HCl}(2.12$ $\mathrm{ml}, 0.42 \mathrm{mmol}$ ). The mixture was stirred at room temperature for $2 \mathrm{~h}$. The mixture was added dropwise to a mixture of saturated aqueous $\mathrm{NaHCO}_{3}(2 \mathrm{ml})$ and EtOAc $(10 \mathrm{ml})$. The layers were separated and the aqueous phase was saturated with $\mathrm{NaCl}$ and then extracted with EtOAc $(10 \mathrm{ml})$. The combined organic layers were dried over $\mathrm{Na}_{2} \mathrm{SO}_{4}$ and filtered before concentration under reduced pressure to afford CXP14.18-037 (113 mg, 85\%) as a pale yellow oil. ${ }^{1} \mathrm{H}$ NMR $\left(400 \mathrm{MHz}, \mathrm{CDCl}_{3}\right): \delta 7.30$ (br s, $\left.1 \mathrm{H}\right), 6.30$ (br s, $1 \mathrm{H}), 4.13(\mathrm{~d}, J=5.0 \mathrm{~Hz}, 1 \mathrm{H}), 4.01(\mathrm{~d}, J=5.0 \mathrm{~Hz}$, $1 \mathrm{H}), 3.55-3.33(\mathrm{~m}, 7 \mathrm{H}), 2.22-2.15(\mathrm{~m}, 2 \mathrm{H}), 1.65-1.53$ (m, 2H), 1.39-1.25 (m, 2H), 1.03 (s, 3H), $0.95(\mathrm{~s}, 3 \mathrm{H}), 0.91$ (t, $J=7.3 \mathrm{~Hz}, 3 \mathrm{H})$.
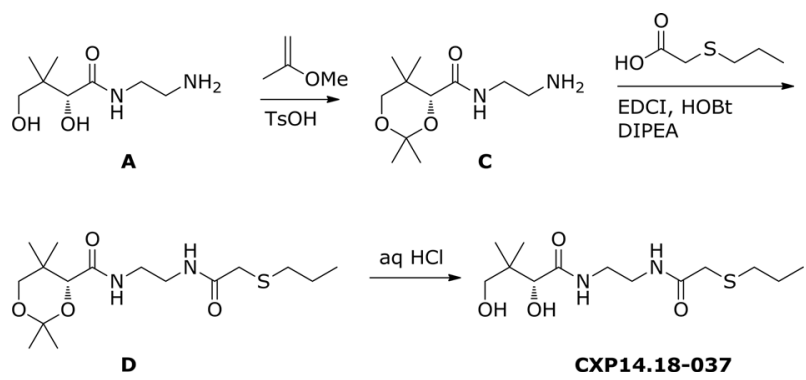

\section{CXP14.18-028}

According to the sequence used for CXP14.18-037. Yield (from C): $55 \%$, colorless oil. ${ }^{1} \mathrm{H}$ NMR $\left(400 \mathrm{MHz}, \mathrm{CD}_{3} \mathrm{OD}\right)$ : $\delta 3.89(\mathrm{~s}, 1 \mathrm{H}), 3.47(\mathrm{~d}, J=10.9 \mathrm{~Hz}, 1 \mathrm{H}), 3.39$ (d, $J=10.9$ $\mathrm{Hz}, 1 \mathrm{H}), 3.40-3.28$ (m, 4H), 2.21-2.15 (m, 2H), 1.65-1.53 (m, 2H), 1.44-1.29 (m, 2H), 0.94-0.91 (m, 9H).

\section{CXP14.18-034}

According to the sequence used for CXP14.18-037. Yield (from C): $37 \%$, pale yellow oil. ${ }^{1} \mathrm{H}$ NMR $(400 \mathrm{MHz}$, $\mathrm{CDCl}_{3}$ ): $\delta 7.25$ (br s, $\left.1 \mathrm{H}\right), 6.32($ br s, $1 \mathrm{H}), 4.02(\mathrm{~d}, J=5.1$ $\mathrm{Hz}, 1 \mathrm{H}), 3.97(\mathrm{~d}, J=5.1 \mathrm{~Hz}, 1 \mathrm{H}), 3.55-3.27(\mathrm{~m}, 7 \mathrm{H}), 2.53$ (t, $J=7.0 \mathrm{~Hz}, 2 \mathrm{H}), 2.31(\mathrm{t}, J=7.4 \mathrm{~Hz}, 2 \mathrm{H}), 2.09$ (s, 3H), $1.99-1.87$ (m, 2H), 1.03 (s, 3H), 0.95 (s, 3H).

\section{CXP14.18-038}

According to the sequence used for CXP14.18-037. Yield (from C): $34 \%$, colorless oil. ${ }^{1} \mathrm{H}$ NMR $\left(400 \mathrm{MHz}, \mathrm{CDCl}_{3}\right)$ : $\delta 7.28($ br s, $1 \mathrm{H}), 6.44(\mathrm{br} \mathrm{s}, 1 \mathrm{H}), 4.03-3.93(\mathrm{~m}, 1 \mathrm{H})$, $3.55-3.33(\mathrm{~m}, 7), 2.90-2.70(\mathrm{~m}, 2 \mathrm{H}), 2.55(\mathrm{q}, J=7.8 \mathrm{~Hz}$, $2 \mathrm{H}), 2.53-2.38(\mathrm{~m}, 2 \mathrm{H}), 1.26(\mathrm{t}, J=7.8 \mathrm{~Hz}, 3 \mathrm{H}), 1.04$ (s, 3H), 0.95 (s, 3H).

\section{Bacterial strains, growth conditions, and MIC assay}

The following bacterial strains were used in this study. $S$. aureus (ATCC6538, ATCC29213, Xen36, and MRSA (clinical isolate kindly provided from RIVM)), S. epidermidis (ATCC12228, ATCC14990 and Bactimm 389 (clinical isolate provided from Bactimm)), S. pyogenes (SS91, SS410 and SS799), Escherichia coli (ATCC25922), Pseudomonas aeruginosa (ATCC15692), Mycobacterium avium (ATCC700898), Mycobacterium abscessus (CIP104536), and Mycobacterium kansasii (ATCC25221).

All strains, except mycobacteria, were grown overnight on Columbian blood agar plates (Thermo Scientific) at $37^{\circ} \mathrm{C}$. Slow growing mycobacteria (SGM, M. avium and M. kansasii) were grown for 5-7 days in Middlebrook 7H9 Broth supplemented with $10 \%$ oleic acid, albumin, dextrose, and catalase (OADC) at $37^{\circ} \mathrm{C}$. Rapid growing mycobacteria (RGM, M. abscessus) were grown for 3 days in Middlebrook 7H9 Broth at $30^{\circ} \mathrm{C}$. S. pyogenes strains were incubated at $5 \% \mathrm{CO}_{2}$, while all other strains grow in normal atmosphere. Liquid cultures of S. aureus, S. epidermidis, E. coli, and P.aeruginosa were grown in Mueller-Hinton Broth (BD Difco) at $37^{\circ} \mathrm{C}$ while shaking and $S$. pyogenes were grown statically in $5 \% \mathrm{CO}_{2}$ at $37^{\circ} \mathrm{C}$ in Todd Hewitt Broth (BD Bacto).

To test the MIC of compounds on S. aureus, S. epidermidis, $S$. pyogenes, $E$. coli, and $P$. aeruginosa overnight cultures were diluted 1:1000 in fresh media and $100 \mu \mathrm{l}$ was added to $100 \mu \mathrm{l}$ of serial diluted compound in 96-well plates. Plates were incubated at $37^{\circ} \mathrm{C}(S$. pyogenes in $5 \%$ $\mathrm{CO}_{2}$, others in normal atmosphere) for $16 \mathrm{~h}$ and MICs were determined optically. The MIC was defined as the first well where no bacterial growth was observed. To test the MIC of compounds on $M$. avium, M. kansasii, and M. abscessus, a 0.5 McFarland suspension was made of the cultured strains during log phase growth. This suspension was then diluted to obtain an inoculum of $1 \times 10^{5}-1 \times 10^{6} \mathrm{CFU} \mathrm{ml}^{-1}$ in Cation Adjusted Mueller-Hinton broth (with 20\% OADC for SGM) and $50 \mu \mathrm{l}$ was added to $50 \mu \mathrm{l}$ of serial diluted compound in 96 -well plates. Plates were incubated at $37^{\circ} \mathrm{C}$ for 7 days for SGM and at $30^{\circ} \mathrm{C}$ for 3 days for RGM. MICs were determined optically. The MIC was defined as the first 
well where no bacterial growth was observed. The results are the median values of at least three independent assays.

Antimicrobial activity of N7-Pan and CXP18.6-012 in the presence of serum was performed as follows: to mimic human serum as much as possible, the highest concentration of serum $(10 \%)$ was used that did not interfere with the optical readout. Complement inactivation of human serum $\left(30 \mathrm{~min}\right.$ at $56^{\circ} \mathrm{C}$ ) was necessary to prevent antimicrobial activity of the complement system. Because heat inactivation of serum also led to decreased vanin activity, we supplemented the serum with fetal bovine serum (FBS) in a ratio of $4: 1$. The vanin activity in FBS is extremely high compared to human serum, leading to a total vanin activity in the assay that resembles full human serum. Furthermore, the standard MIC assay was performed as described above.

\section{LC-MS analysis}

To examine the stability of analogs in vitro, N5-Pan, its bioisostere CXP18.6-013, N7-Pan and its bioisostere CXP18.6-12 were incubated for $16 \mathrm{~h}$ at room temperature in $500 \mu \mathrm{M}$ potassium buffer with and without $10 \%$ fetal bovine serum as a source of pantetheinase activity. Samples were taken and analyzed by LC-MS using a Shimadzu LC10ATvp HPLC coupled to a Shimadzu LCMS2010A mass spectrometer. The elution of the following molecules were shown: N5-Pan and CXP18.6-013 (271 [M- $\mathrm{H}_{2} \mathrm{O}+\mathrm{H}$ $\left.{ }^{+}\right]$), N7-Pan and CXP18.6-012 (299[M- $\left.\left.\mathrm{H}_{2} \mathrm{O}+\mathrm{H}^{+}\right]\right)$, pantothenate $\left(220\left[\mathrm{M}+\mathrm{H}^{+}\right]\right)$and $\mathrm{N} 2$-(aminoethyl)-2,4-dihydroxy-3,3-dimethylbutyramide (191 $\left.\left[\mathrm{M}+\mathrm{H}^{+}\right]\right)$.

\section{Cytotoxicity assay}

Primary human keratinocytes obtained from biopsies of healthy volunteers were cultured following the RheinwaldGreen system at $37^{\circ} \mathrm{C}$ and $5 \% \mathrm{CO}_{2}$ [24]. Cells were grown until they reached confluency. Compounds were added to these cultures at a concentration of $100 \mu \mathrm{M}$ and effect on growth and toxicity was determined microscopically after $24 \mathrm{~h}$. Cytotoxicity was detected using the LDH cytotoxicity detection kit according to the manufacturer's protocol (Roche Applied Science, IN).

\section{Results}

\section{Synthesis of N7-pan bioisosteres}

We investigated the structure-activity relationship of pantothenamide modifications by varying the N7-Pan molecule on three different positions, as indicated in Fig. 1b: the $\mathrm{C} 2$ linker between the two amides, the second amide bond and the right hand part of the molecule (further referred to as side chain). Table 1 lists the structural modifications in the $\mathrm{C} 2$ linker and amide bond of N7-Pan, and their effects on the minimal inhibitory concentration (MIC) values. It turned out that only a C2 linker was allowed. Substitution by an alkene or aromatic moiety was not allowed. The amide bond was probed by replacing with different bioisosteres, whilst keeping the C2 linker intact. Replacement by a keto, ester or a sulfonamide moiety was not allowed. Replacement by 5-membered ring amide bioisosteres was in general not successful, although in some cases minor activity was demonstrated. The only effective modification which yielded activities comparable to the parent compound was substitution of the amide bond by an inverted amide as shown in compound CXP18.6-012. Like N7-Pan, none of its bioisosteres showed activity against the Gram-negative bacteria that were tested (E. coli and P. aeruginosa) or the Mycobacterium species that were tested (M. avium, M. abscessus and M. kansasii). Some bioisosteres showed weak activities against $S$. epidermidis and $S$. pyogenes (MIC between 8 and $32 \mu \mathrm{g} \mathrm{ml}^{-1}$ ). Only bioisostere CXP18.6012 showed activity against $S$. aureus, with a MIC value of 2 $\mu \mathrm{g} \mathrm{ml}^{-1}$, which is close to the potency of the parent compound N7-Pan. However, this modification decreased the potency towards $S$. epidermidis from 0.5 to $8 \mu \mathrm{g} \mathrm{ml}^{-1}$, whereas the sensitivity towards $S$. pyogenes was decreased from 2 to $32 \mu \mathrm{g}$ $\mathrm{ml}^{-1}$. In addition, we synthesized the inverted amide bioisostere of another prototypical pantothenamide, N5-Pan, designated as CXP18.6-013 (see also Supplemental Table 1). This compound showed good activity towards S.pyogenes $\left(2 \mu \mathrm{g} \mathrm{ml}^{-1}\right)$ and weak activity towards $S$. epidermidis and $S$. aureus (resp. 16 and $32 \mu \mathrm{g} \mathrm{ml}^{-1}$ ). The experimental details on the synthesis of the compounds of Table 1 are given in online Supplemental File S1, with the exception of CXP18.6-012 which can be found in the Materials and Methods section, and N7-Pan, which has been described before [2].

\section{Stability of inverted pantothenamides}

We incubated the prototypical pantothenamides N5-Pan and N7-Pan as well as their inverted amide bioisosteres CXP18.6-012 and CXP18.6-013 in the presence and absence of fetal bovine serum, and analyzed the stability towards vanin-mediated hydrolysis, using LC-MS analysis. In Fig. 2a, c total degradation of N5-Pan and N7-Pan by serum is shown as the disappearance of the red peak of the parent compound, whereas the hydrolysis product pantothenate emerges (blue peak). Figures $2 \mathrm{~b}$, d show that the inverted pantothenamides CXP18.6-013 and CXP18.6-012 remain stable after overnight incubation in a serumcontaining buffer. 
Table 1 Bioisosteres of prototypic pantothenamide N7-Pan

\begin{tabular}{|c|c|c|c|c|c|c|c|c|c|}
\hline Compound & Structure & $\begin{array}{c}\text { S.aureus } \\
\text { ATCC6538 }\end{array}$ & $\begin{array}{l}\text { S.epidermidis } \\
\text { ATCC12228 }\end{array}$ & $\begin{array}{l}\text { S.pyogenes } \\
\text { SS91 }\end{array}$ & $\begin{array}{c}\text { E.coli } \\
\text { ATCC25922 }\end{array}$ & $\begin{array}{l}\text { P.aerugenosa } \\
\text { ATCC15692 }\end{array}$ & $\begin{array}{c}\text { M.avium } \\
\text { ATCC700898 }\end{array}$ & $\begin{array}{l}\text { M.abscessus } \\
\text { CIP105536 }\end{array}$ & $\begin{array}{l}\text { M.Kansasif } \\
\text { ATCC25221 }\end{array}$ \\
\hline N7-Pan & & 1 & 0,5 & 2 & $>32$ & $>32$ & $>32$ & $>32$ & $>32$ \\
\hline CXP14.1-057 & & $>32$ & $>32$ & $>32$ & $>32$ & $>32$ & $>32$ & $>32$ & $>32$ \\
\hline CXP14.1-080 & & $>32$ & $>32$ & $>32$ & $>32$ & $>32$ & $>32$ & $>32$ & $>32$ \\
\hline CXP14.19-002 & & $>32$ & $>32$ & 8 & $>32$ & $>32$ & $>32$ & $>32$ & $>32$ \\
\hline CXP14.14-016 & & $>32$ & $>32$ & $>32$ & $>32$ & $>32$ & $>32$ & $>32$ & $>32$ \\
\hline CXP14.14-024 & & $>32$ & $>32$ & $>32$ & $>32$ & $>32$ & $>32$ & $>32$ & $>32$ \\
\hline CXP14.19-005 & & $>32$ & $>32$ & $>32$ & $>32$ & $>32$ & $>32$ & $>32$ & $>32$ \\
\hline CXP14.19-006 & & $>32$ & $>32$ & $>32$ & $>32$ & $>32$ & $>32$ & $>32$ & $>32$ \\
\hline CXP14.19-012 & & $>32$ & $>32$ & $>32$ & $>32$ & $>32$ & $>32$ & $>32$ & $>32$ \\
\hline CXP14.19-027 & & $>32$ & $>32$ & $>32$ & $>32$ & $>32$ & $>32$ & $>32$ & $>32$ \\
\hline CXP14.19-093 & & $>32$ & $>32$ & $>32$ & $>32$ & $>32$ & $>32$ & $>32$ & $>32$ \\
\hline CXP14.19-041 & & $>32$ & 16 & $>32$ & $>32$ & $>32$ & $>32$ & $>32$ & $>32$ \\
\hline CXP14.19-094 & & $>32$ & $>32$ & $>32$ & $>32$ & $>32$ & $>32$ & $>32$ & $>32$ \\
\hline CXP14.19-103 & & $>32$ & $>32$ & 8 & $>32$ & $>32$ & $>32$ & $>32$ & $>32$ \\
\hline CXP14.19-104 & & $>32$ & $>32$ & $>32$ & $>32$ & $>32$ & $>32$ & $>32$ & $>32$ \\
\hline CXP14.19-107 & & $>32$ & $>32$ & $>32$ & $>32$ & $>32$ & $>32$ & $>32$ & $>32$ \\
\hline CXP14.19-112 & & $>32$ & $>32$ & 32 & $>32$ & $>32$ & $>32$ & $>32$ & $>32$ \\
\hline CXP14.20-017 & & $>32$ & $>32$ & $>32$ & $>32$ & $>32$ & $>32$ & $>32$ & $>32$ \\
\hline CXP14.20-020 & & $>32$ & $>32$ & $>32$ & $>32$ & $>32$ & $>32$ & $>32$ & $>32$ \\
\hline CXP14.20-029 & & $>32$ & $>32$ & 32 & $>32$ & $>32$ & $>32$ & $>32$ & $>32$ \\
\hline CXP14.22-027 & & $>32$ & $>32$ & $>32$ & $>32$ & $>32$ & $>32$ & $>32$ & $>32$ \\
\hline CXP14.23-017 & & $>32$ & $>32$ & $>32$ & $>32$ & $>32$ & $>32$ & $>32$ & $>32$ \\
\hline CXP14.23-018 & & $>32$ & $>32$ & $>32$ & $>32$ & $>32$ & $>32$ & $>32$ & $>32$ \\
\hline CXP18.4-033 & & $>32$ & $>32$ & $>32$ & $>32$ & $>32$ & $>32$ & $>32$ & $>32$ \\
\hline CXP14.24-011 & & $>32$ & $>32$ & $>32$ & $>32$ & $>32$ & $>32$ & $>32$ & $>32$ \\
\hline CXP18.6-012 & & 2 & 8 & 32 & $>32$ & $>32$ & $>32$ & $>32$ & $>32$ \\
\hline
\end{tabular}

MICs were denoted as $\mu \mathrm{g} \mathrm{ml}^{-1}$

MICs up to $32 \mu \mathrm{g} \mathrm{ml}^{-1}$ are represented in bold 


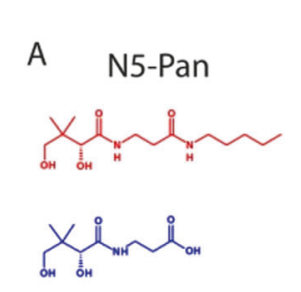

without serum

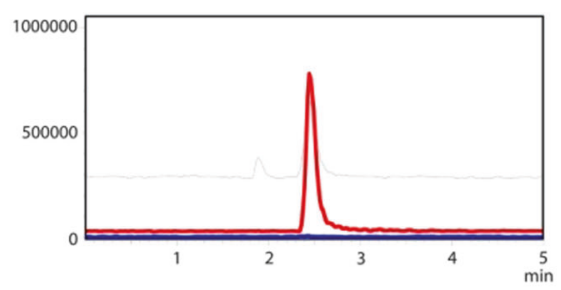

B

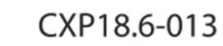<smiles>CCCCC(C)CCCC(C)C(C)C(C)(C)C(C)(C)C</smiles><smiles>CCCCCC(C)C(C)C(C)(C)C</smiles>

C

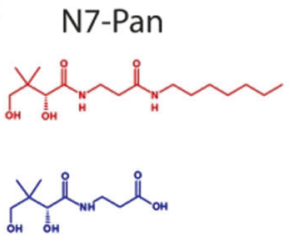

D CXP18.6-012<smiles>CCCCCCC(C)CCCC(C)C(C)C(C)C(C)(C)C</smiles>

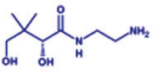
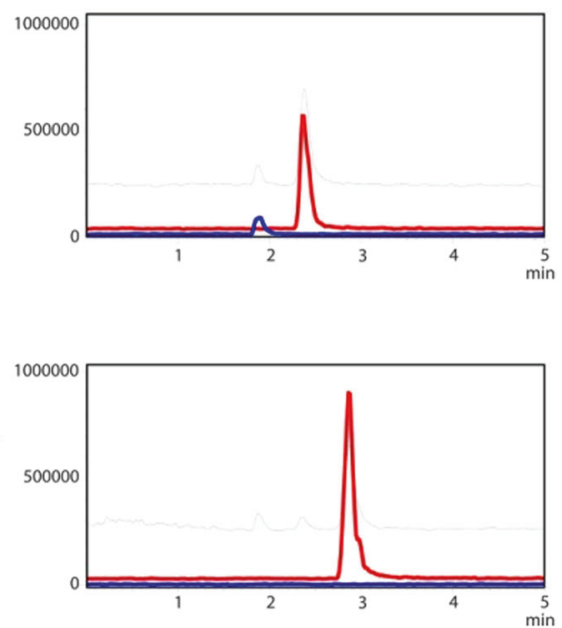

Fig. 2 Stability of inverted pantothenamides in serum. The stability of compounds was measured using LC-MS analysis after overnight incubation in buffer with or without $10 \%$ fetal bovine serum. Fetal bovine serum contains high levels of pantetheinase activity. a N5-Pan (red line) was stable in buffer, but completely degraded when serum was added. The blue peak represents pantothenate, the product after pantetheinase-derived degradation. b CXP18.6-013 (red line), the inverted amide of N5-Pan remain stable in serum-containing buffer, indicating it is protected against degradation by vanins. The

\section{Activity of inverted pantothenamides under physiological conditions}

We then investigated whether inverted pantothenamides would retain their ability to kill bacteria, even in the presence of serum. To test this, we performed MIC assays in Mueller-Hinton medium to which $10 \%$ serum was added. We tested both human serum and fetal bovine serum (FBS). Human serum was first decomplemented at $56{ }^{\circ} \mathrm{C}$, which also partly destroys its vanin activity. FBS, which has an extremely high vanin activity, was used without heat inactivation, which allowed testing of the compounds in the presence of a vanin activity which equals that of $100 \%$ human serum. Table 2 shows that
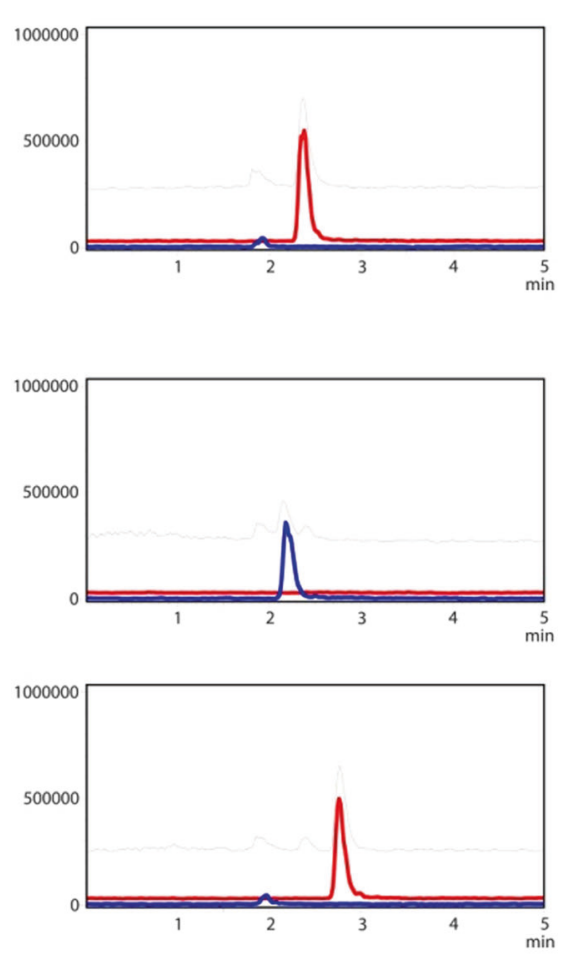

with serum
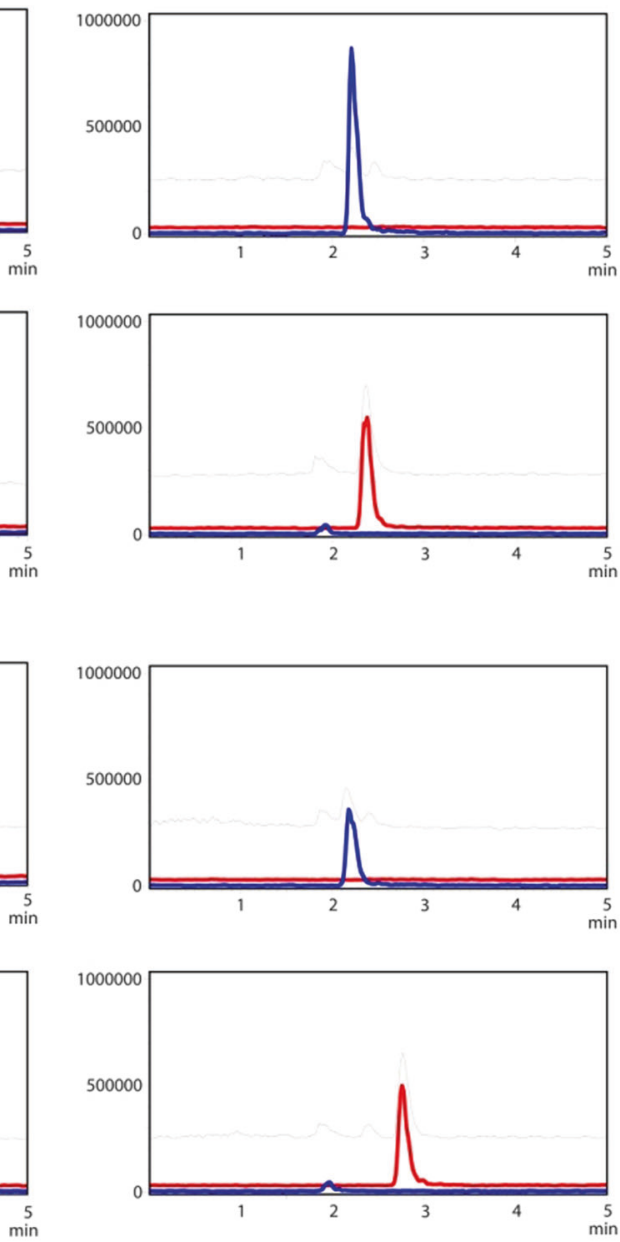
Table 2 Effect of serum on MIC of N7-Pan and CXP18.6-012 against S. aureus ATCC6538

Compound $\quad \begin{gathered}\begin{array}{c}\text { without serum } \\ \mu \mathrm{g} \mathrm{ml}^{-1}\end{array} \\ \begin{array}{c}\text { with serum } \\ \mu \mathrm{ml}^{-1}\end{array}\end{gathered}$

abscessus, and M. kansasii. Both aliphatic and aromatic substitutions provided active compounds. With aliphatic side chains the optimum length was $\mathrm{C} 7$ and $\mathrm{C} 9$. In case of shorter chain length (C5, C5 with a heteroatom), activity was mainly observed against $S$. pyogenes (e.g., CXP18.6013, CXP14.18-028, CXP14.18-037, and CXP14.18-034). It turned out that the $\mathrm{C} 7$ aliphatic chain could be replaced by ethylaromatics. In case of a phenyl being present in the side chain, a comparable activity profile was found (see CXP18.6-064, CXP18.6-017, and CXP18.6-069). In case of aromatic heterocycles, activity against $S$. pyogenes became dominant (CXP18.6-047 and CXP18.6-057). None of the tested inverted pantothenamides was able to inhibit growth of Gram-negative bacteria or Mycobacterium species at relevant concentrations $\left(\leq 32 \mu \mathrm{g} \mathrm{ml}^{-1}\right)$. The compounds that showed significant activity towards one of the Grampositive bacteria were tested against multiple strains of $S$. aureus, S. epidermidis, and S. pyogenes (see Table 3). Overall, the differences between strains were very small. The most potent inverted pantothenamides against $S$. aureus tested here are CXP18.6-17 $\left(1-2 \mu \mathrm{g} \mathrm{ml}^{-1}\right), \mathrm{CXP} 18.6-012$ $\left(2-8 \mu \mathrm{g} \mathrm{ml}^{-1}\right)$, CXP18.6-014 $\left(2-8 \mu \mathrm{g} \mathrm{ml}^{-1}\right)$, and CXP18.6$069\left(2-8 \mu \mathrm{g} \mathrm{ml}^{-1}\right)$. Towards $S$. epidermidis the most potent inverted pantothenamides were CXP18.6-064 $\left(1 \mu \mathrm{g} \mathrm{ml}^{-1}\right)$, CXP18.6-014 $\left(2 \mu \mathrm{g} \mathrm{ml}^{-1}\right)$, CXP18.6-69 $\left(1-2 \mu \mathrm{g} \mathrm{ml}^{-1}\right)$, and CXP18.6-17 $\left(2-4 \mu \mathrm{g} \mathrm{ml}^{-1}\right)$. Strains of S.pyogenes were most sensitive to CXP14.18-028 $\left(2 \mu \mathrm{g} \mathrm{ml}^{-1}\right)$, CXP14.18$037\left(2-4 \mu \mathrm{g} \mathrm{ml}^{-1}\right)$, and CXP14.18-005 (2-8 $\left.\mu \mathrm{g} \mathrm{ml}^{-1}\right)$.

\section{In vitro toxicology}

Finally, we used cultured primary human keratinocytes to obtain limited in vitro toxicology data on inverted pantothenamides. Using LDH release as a measure of viability, we did not detect cytotoxicity of any of the compounds that showed antimicrobial activity up to concentrations of 100 $\mu \mathrm{M}\left(\sim 30 \mu \mathrm{g} \mathrm{ml}^{-1}\right)$.

\section{Discussion}

In the present study we describe a new class of stable pantothenamide bioisosteres that display antibiotic

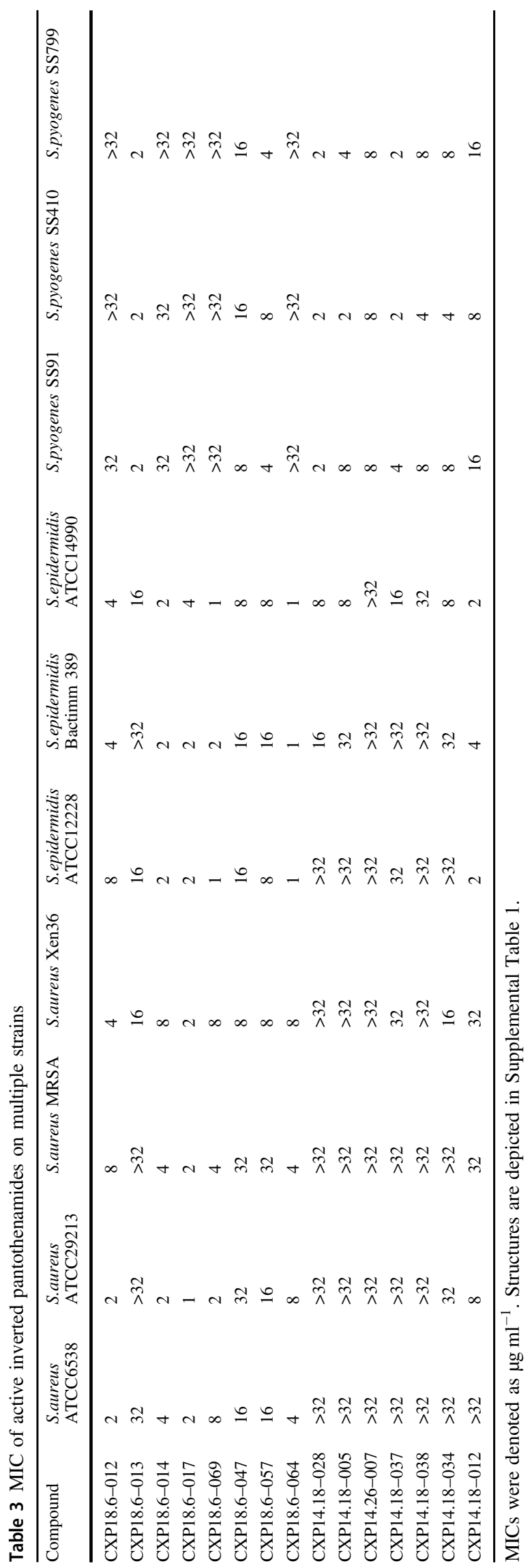


activity against staphylococci and streptococci. These compounds target a biochemical pathway that is distinct from currently marketed drugs, and their activity appears to be primarily against clinically relevant Gram-positive species. As there is a strong medical need for improved small-spectrum antibiotics, stable pantothenamides with improved potency may be moved forward as promising compounds for clinical use.

Previous studies have demonstrated that pantothenamide antibiotics based on the pantothenate/pantetheine scaffold are labile in biological fluids due to hydrolysis of the amide bond by serum vanins [13-16]. Our data reveal that inversion of the amide bond afforded a considerable increase of stability whilst largely preserving the biological activity [25]. A recent paper by Barnard et al. [20] reported that the inversion of the amide bond had a dramatic effect on antibiotic activity towards the $S$. aureus RN2440 strain. This is in contrast to our findings. We have tested multiple strains and species, and found similar MICs among strains. The basis for the discrepancy between these studies is presently unclear, but is currently actively being pursued in collaboration with Strauss and co-workers. Other structural modifications, reported for antimalarial pantothenamides, that increased the stability include introduction of a methyl group in the C2 linker [19] and variation of the linker length [8]. We further explored structural modifications at the side chain, which did not lead to improved potency compared to the parent compound. Remarkably, the taxon-specificity was clearly dependent on the structural modifications in the molecule. These were found to affect both the specificity at the genus and the species level for Gram-positive organisms studied here. We do not think that the pantothenamides as a class are selective for Gram-positive organisms. In the original paper by Clifton et al[2]. where N5-Pan and N7-Pan were first described, there was significant activity of N5-Pan against the Gram-negative organism E. coli. Here we have developed compounds based on N7-Pan, which appear to be more potent towards Gram-positive organisms. It has to be noted that we only tested a number of clinically relevant genera of Gram-positive and Gram-negative bacteria. A more extensive screen of bacterial species is required to establish the sensitivity of other Gram-negative organisms. The observed lack of sensitivity of $E$. coli might be explained by the fact that N7-Pan (and possibly also its derivatives) is a substrate for TolC-dependent efflux pumps, as reported by Zhang et al. [10].

Our present study suggests that pantothenamides may be further optimized to yield small-spectrum antibiotics that could target a pathogen without affecting the complete human microbiome. This would be a major advance to avoid the consequences of broad spectrum antibiotics such gut microbiota dysbiosis, thereby reducing antibiotic- associated complications such as diarrhea, Clostridium difficile infections or candidiasis. An example that such specificity is feasible is the development of Debio 1450 (now known as afabicin), an antibiotic candidate with a novel mechanism of action, currently in phase II clinical development for intravenous and oral treatment of staphylococcal infections [26]. It specifically targets Staphylococcus by inhibition of FabI, an enzyme essential for fatty acid synthesis in this genus. Debio 1450 shows a high potency against staphylococci, particularly MRSA, without crossresistance to other antibiotics, including other agents active against staphylococci. Interestingly, this indicates that bacterial fatty acid synthesis is a valid antibiotic target, at least for S. aureus, which has been questioned previously [27]. As CoA is also required for fatty acid synthesis, pantothenamides may also act on bacterial fatty acid synthesis. Addition of serum, which is a source of host fatty acids, to our MIC assays did not significantly inhibit the antibiotics effects. This indicates that exogenous available free fatty acids do not interfere with the mechanism of action.

The mechanism of action of the prototypic pantothenamides has been investigated previously and appears largely dependent on the PanK type of the organism. For E.coli, which has a PanK $\mathrm{I}$ type enzyme, the presumed mechanism of action of the pantothenamide N5-pan has been investigated in detail. The formation of coenzyme $\mathrm{A}$ antimetabolites [9] that interferes with fatty acid synthetic enzymes [11] and endogenous pantothenate biosynthesis [28] are two affected pathways that are interrupted. It was also reported that N5-Pan could inhibit the growth of $S$. pneumoniae and that this effect was probably due to fatty acid synthesis inhibition as it could be outcompeted with oleate [10]. The molecular mechanism by which pantothenamides inhibit growth of other Gram-positive bacteria is currently unknown, with an exception for S. aureus. In contrast to other gram-positive bacteria, $S$. aureus has a PanK $_{\text {II }}$ type enzyme that accepts pantothenamides as a substrate [8]. The co-crystal structures of SaPanK $\mathrm{KI}_{\mathrm{II}}$ and N7pan revealed that pantothenamides are phosphorylated but remain trapped in the active site [7]. Given the differential effects of many of our compounds towards $S$. aureus and $S$. pyogenes, it is likely that the modes of action are distinct.

Clearly, additional efforts are required to identify improved inhibitors that may progress to the clinic. So far we have relied on ligand-based design, but preferably we would direct future campaigns to structure-based design. We are currently investigating the mechanism of action of the pantothenamide bioisosteres.

Acknowledgements This study was partly funded by a grant from the Dutch Burns Foundation to P.Zeeuwen and J.Schalkwijk (grant WO/ 16.101). 


\section{Compliance with ethical standards}

Conflict of interest The authors declare that they have no conflict of interest.

Publisher's note: Springer Nature remains neutral with regard to jurisdictional claims in published maps and institutional affiliations.

Open Access This article is licensed under a Creative Commons Attribution 4.0 International License, which permits use, sharing, adaptation, distribution and reproduction in any medium or format, as long as you give appropriate credit to the original author(s) and the source, provide a link to the Creative Commons license, and indicate if changes were made. The images or other third party material in this article are included in the article's Creative Commons license, unless indicated otherwise in a credit line to the material. If material is not included in the article's Creative Commons license and your intended use is not permitted by statutory regulation or exceeds the permitted use, you will need to obtain permission directly from the copyright holder. To view a copy of this license, visit http://creativecommons. org/licenses/by/4.0/.

\section{References}

1. Spry C, Kirk K, Saliba KJ. Coenzyme A biosynthesis: an antimicrobial drug target. FEMS Microbiol Rev. 2008;32:56-106.

2. Clifton G, Bryant SR, Skinner CG. N'-(substituted) pantothenamides, antimetabolites of pantothenic acid. Arch Biochem Biophys. 1970;137:523-8.

3. Leonardi R, Chohnan S, Zhang YM, Virga KG, Lee RE, Rock CO, Jackowski S. A pantothenate kinase from Staphylococcus aureus refractory to feedback regulation by coenzyme A. J Biol Chem. 2005;280:3314-22.

4. Virga KG, Zhang YM, Leonardi R, Ivey RA, Hevener K, Park HW, Jackowski S, Rock CO, Lee RE. Structure-activity relationships and enzyme inhibition of pantothenamide-type pantothenate kinase inhibitors. Bioorg Med Chem. 2006;14: 1007-20.

5. Choudhry AE, Mandichak TL, Broskey JP, Egolf RW, Kinsland C, Begley TP, Seefeld MA, Ku TW, Brown JR, Zalacain M, Ratnam K. Inhibitors of pantothenate kinase: novel antibiotics for staphylococcal infections. Antimicrob Agents Chemother. 2003; 47:2051-5.

6. Hoegl A, Darabi H, Tran E, Awuah E, Kerdo ES, Habib E, Saliba KJ, Auclair K. Stereochemical modification of geminal dialkyl substituents on pantothenamides alters antimicrobial activity. Bioorg Med Chem Lett. 2014;24:3274-7.

7. Hughes SJ, Barnard L, Mottaghi K, Tempel W, Antoshchenko T, Hong BS, Allali-Hassani A, Smil D, Vedadi M, Strauss E, Park HW. Discovery of potent pantothenamide inhibitors of Staphylococcus aureus pantothenate kinase through a minimal SAR study: inhibition is due to trapping of the product. ACS Infect Dis. 2016;2:627-41.

8. de Villiers M, Barnard L, Koekemoer L, Snoep JL, Strauss E. Variation in pantothenate kinase type determines the pantothenamide mode of action and impacts on coenzyme A salvage biosynthesis. FEBS J. 2014;281:4731-53.

9. Strauss E, Begley TP. The antibiotic activity of Npentylpantothenamide results from its conversion to ethyldethiacoenzyme a, a coenzyme a antimetabolite. J Biol Chem. 2002;277:48205-9.
10. Zhang YM, Frank MW, Virga KG, Lee RE, Rock CO, Jackowski $\mathrm{S}$. Acyl carrier protein is a cellular target for the antibacterial action of the pantothenamide class of pantothenate antimetabolites. J Biol Chem. 2004;279:50969-75.

11. Thomas J, Cronan JE. Antibacterial activity of Npentylpantothenamide is due to inhibition of coenzyme a synthesis. Antimicrob Agents Chemother. 2010;54:1374-7.

12. Zhang YM, White SW, Rock CO. Inhibiting bacterial fatty acid synthesis. J Biol Chem. 2006;281:17541-4.

13. Jansen PA, Hermkens PH, Zeeuwen PL, Botman PN, Blaauw RH, Burghout P, van Galen PM, Mouton JW, Rutjes FP, Schalkwijk J. Combination of pantothenamides with vanin inhibitors as a novel antibiotic strategy against gram-positive bacteria. Antimicrob Agents Chemother. 2013;57:4794-4800.

14. Spry C, Macuamule C, Lin Z, Virga KG, Lee RE, Strauss E, Saliba KJ. Pantothenamides are potent, on-target inhibitors of plasmodium falciparum growth when serum pantetheinase is inactivated. PLoS One. 2013;8:e54974.

15. Jansen PA, Zeeuwen PL, Schalkwijk J, Rutjes FP, Ritzen B, Hermkens PH. Pantothenic acid derivatives and their use in the treatment of microbial infections. WO2011152720. 2011.

16. Jansen PA, Schalkwijk J, Rutjes FP, Sauerwein R, Hermkens PH. Derivatives of pantothenic acid and their use for the treatment of malaria. WO2011152721. 2011.

17. Jansen PA, van Diepen JA, Ritzen B, Zeeuwen PL, Cacciatore I, Cornacchia C, van Vlijmen-Willems IM, de Heuvel E, Botman PN, Blaauw RH, Hermkens PH, Rutjes FP, Schalkwijk J. Discovery of small molecule vanin inhibitors: new tools to study metabolism and disease. ACS Chem Biol. 2013;8: $530-4$.

18. Schalkwijk J, Jansen P. Chemical biology tools to study pantetheinases of the vanin family. Biochem Soc Trans. 2014;42:1052-5.

19. Macuamule CJ, Tjhin ET, Jana CE, Barnard L, Koekemoer L, de Villiers M, Saliba KJ, Strauss E. A pantetheinase-resistant pantothenamide with potent, on-target, and selective antiplasmodial activity. Antimicrob Agents Chemother. 2015;59: 3666-8.

20. Barnard L, Mostert KJ, van Otterlo WAL, Strauss E. Developing pantetheinase-resistant pantothenamide antibacterials: structural modification impacts on PanK interaction and mode of action. ACS Infect Dis. 2018;4:736-43.

21. de Villiers M, Macuamule C, Spry C, Hyun YM, Strauss E, Saliba KJ. Structural modification of pantothenamides counteracts degradation by pantetheinase and improves antiplasmodial activity. ACS Med Chem Lett. 2013;4:784-9.

22. Guan J, Hachey M, Puri L, Howieson V, Saliba KJ, Auclair K. A cross-metathesis approach to novel pantothenamide derivatives. Beilstein J Org Chem. 2016;12:963-8.

23. Howieson VM, Tran E, Hoegl A, Fam HL, Fu J, Sivonen K, Li XX, Auclair K, Saliba KJ. Triazole substitution of a labile amide bond stabilizes pantothenamides and improves their antiplasmodial potency. Antimicrob Agents Chemother. 2016;60: 7146-52.

24. Rheinwald JG, Green H. Serial cultivation of strains of human epidermal keratinocytes: the formation of keratinizing colonies from single cells. Cell. 1975;6:331-44.

25. Hermkens PH, Schalkwijk J, Jansen PAM, Botman PN. Pantothenamide analogues. WO2016072854 A2. 2016.

26. Kaplan N, Albert M, Awrey D, Bardouniotis E, Berman J, Clarke T, Dorsey M, Hafkin B, Ramnauth J, Romanov V, Schmid MB, Thalakada R, Yethon J, Pauls HW. Mode of action, in vitro activity, and in vivo efficacy of AFN-1252, a selective 
antistaphylococcal FabI inhibitor. Antimicrob Agents Chemother. 2012;56:5865-74.

27. Brinster S, Lamberet G, Staels B, Trieu-Cuot P, Gruss A, Poyart C. Type II fatty acid synthesis is not a suitable antibiotic target for Gram-positive pathogens. Nature. 2009;458:83-6.
28. Arnott ZLP, Nozaki S, Monteiro DCF, Morgan HE, Pearson AR, Niki H, Webb ME. The mechanism of regulation of pantothenate biosynthesis by the PanD-PanZ.AcCoA complex reveals an additional mode of action for the antimetabolite N-pentyl pantothenamide (N5-Pan). Biochemistry. 2017;56:4931-9. 